\title{
Debris flow event on Osorno volcano, Chile, during summer 2017: new interpretations for chain processes in the southern Andes
}

\author{
Ivo Janos Fustos-Toribio ${ }^{1}$, Bastian Morales-Vargas ${ }^{2,3}$, Marcelo Somos-Valenzuela ${ }^{3,4}$, Pablo Moreno-Yaeger ${ }^{1,5}$, \\ Ramiro Muñoz-Ramirez ${ }^{2}$, Ines Rodriguez Araneda ${ }^{2}$, and Ningsheng Chen ${ }^{6}$ \\ ${ }^{1}$ Department of Civil Engineering, University of La Frontera, Francisco Salazar 1145, Temuco, Chile \\ ${ }^{2}$ Departamento de Obras Civiles y Geología, Facultad de Ingeniería, Universidad Católica de Temuco, \\ Rudecindo Ortega 02950, Temuco, Chile \\ ${ }^{3}$ Department of Forest Sciences, Faculty of Agriculture and Forest Sciences, Universidad de La Frontera, \\ Av. Francisco Salazar 01145, Temuco, 4780000, Chile \\ ${ }^{4}$ Butamallín Research Center for Global Change, University of La Frontera, Av. Francisco Salazar 01145, \\ Temuco, 4780000, Chile \\ ${ }^{5}$ Department of Geoscience, University of Wisconsin-Madison, 1215 West Dayton St., Madison, WI 53706, USA \\ ${ }^{6}$ Key Laboratory of Mountain Hazards and Surface Processes, Institute of Mountain Hazards and Environment, \\ Chinese Academy of Sciences, Chengdu 610041, China
}

Correspondence: Marcelo Somos-Valenzuela (marcelo.somos@ufrontera.cl) and Ivo Janos Fustos-Toribio (ivo.fustos@ufrontera.cl)

Received: 9 March 2021 - Discussion started: 30 March 2021

Revised: 20 August 2021 - Accepted: 8 September 2021 - Published: 8 October 2021

\begin{abstract}
Debris flow generation in volcanic zones in the southern Andes has not been widely studied, despite the enormous economic and infrastructure damage that these events can generate. The present work contributes to the understanding of these dynamics based on a study of the 2017 Petrohué debris flow event from two complementary points of view. First, a comprehensive field survey allowed us to determine that a rockfall initiated the debris flow due to an intense rainfall event. The rockfall lithology corresponds to lava blocks and autobrecciated lavas, predominantly over $1500 \mathrm{~m}$ a.s.l. Second, the process was numerically modelled and constrained by in situ data collection and geomorphological mapping. The event was studied by back analysis using the height of flow measured on Route CH-255 with errors of $5 \%$. Debris flow volume has a high sensitivity with the initial water content in the block fall zone, ranging from $4.7 \times 10^{5}$ up to $5.5 \times 10^{5} \mathrm{~m}^{3}$, depending on the digital elevation model (DEM) used. Therefore, debris flow showed that the zone is controlled by the initial water content available previous to the block fall. Moreover, our field data suggest that future debris flows events can take place, removing material from the volcanic edifice. We conclude that similar events could
\end{abstract}

occur in the future and that it is necessary to increase the mapping of zones with autobrecciated lava close to the volcano summit. The study contributes to the understanding of debris flows in the southern Andes since the Osorno volcano shares similar features with other stratovolcanoes in the region.

\section{Introduction}

Landslide processes are among the most important natural hazards in developing countries due to their low resilience, generating damage to human life, property and engineering projects in all the mountainous areas of the world every year (Martha et al., 2010; Alimohammadlou et al., 2013; Sepúlveda et al., 2014; Fustos et al., 2020). Debris flows are an important type of mass wasting, described as one of the most dangerous of these processes due to their high velocity, the damage that they cause and the extensive areas affected (Jakob et al., 2005). Nevertheless, debris flows studies in volcanic zones are limited, where only primary volcanically originated processes like lahars have been studied. The 
present work evaluates the generation of debris flows, taking the 2017 Petrohué event as a case study. This event caused severe economic losses to one of the most popular tourist attractions in southern Chile (INE, 2018).

Debris flows are very destructive processes in active zones in the Andes, especially in volcanic areas independent of their trigger (Sosio et al., 2011). The northern Andes show examples like the 1985 Nevados del Ruiz eruption. The volcanic activity triggered a lahar flow, which claimed at least 25000 lives (Naranjo et al., 1986). In December 1999, a mud and debris flow in Venezuela caused the loss of 30000 lives (Wieczorek et al., 2000). Rock and soil movements, debris avalanches, debris, mudflows, and the resulting floods destroyed about $40 \mathrm{~km}$ of the trans-Ecuadorian oil pipeline and the only highway from Quito to Ecuador's north-eastern rainforests and oil fields. This phenomenon was caused by heavy rain and two earthquakes in 1987 (Schuster et al., 1996). In 2017, a rainfall-induced landslide event with more than 600 shallow landslides was triggered in Colombia. Following the intense rainfall, landslides and the subsequent Mocoa debris flow (MDF) event killed up to 333 people (García-Delgado et al., 2019). Moreover, the central Andes have experienced massive debris flow events like the ones in the Lastarria volcano (Rodríguez et al., 2020). The collapse of part of the edifice triggered a $270 \mathrm{~km} \mathrm{~h}^{-1}$ volcanic debris avalanche. Catastrophic debris flows occurred on Huascarán (an extinct volcano), Peru, in 1962 and 1970, triggered by ice and rock, which were swept down from the northern peak of the mountain because of an earthquake ( $\left.M_{\mathrm{w}} 7.9\right)$. The 1962 and 1970 events are estimated to have caused $\sim 7000$ deaths (Evans et al., 2009; Tacconi Stefanelli et al., 2017; Bueechi et al., 2018). Until now, only scarce volcano-related debris flows have been reported in the southern Andes. A hyperconcentrated flow occurred days after the 2008 volcanic eruption of the Chaitén volcano. The trigger of the event was related to intense rainfall over ash deposits within days of cessation of the eruption (Pierson et al., 2013). Therefore, the connection between debris flow and volcanic environments in the Andes has been covered in the past in the northern and central Andes. However, they are still only superficially studied in the southern Andes (Korup et al., 2019).

In the southern Andes, volcanic edifices are covered by materials that could produce recurrent debris flows, moulding the relief. The debris flows reported currently in the literature on volcanoes are mainly the result of snow and ice melting during eruptions in the form of lahar (Johnson and Palma, 2015; Major et al., 2016; Thouret et al., 2020). Nevertheless, few works address the relation between the debris flows generated by stratigraphic conditions in volcanic systems and the morphology of the edifice. Their spatial and temporal extension has also been little studied; these are very important since the number of debris flows in volcanic systems has increased in recent years (Pierson, 1995; Aguilar et al., 2014; Korup et al., 2019; Thouret et al., 2020).
The present work seeks to advance our comprehension of the generation of debris flows in volcanic edifices in the southern Andes. An atypical debris flow event of 8 January 2017 (southern summer) on Osorno volcano (southern Andes) was assessed. The geomorphological and geological factors influencing the generation of the debris flow event were studied, estimating the conditions which triggered the event through back analysis using the r.avaflow model. Finally, we discuss whether the event might be recurrent in time or whether it is part of the normal cycle of the volcano; this knowledge will assist in assessing the risk of debris flows in the southern Andes.

\section{Study area}

Osorno is a stratovolcano that is part of the active volcanic arc of the southern Andes, called the Southern Volcanic Zone (SVZ). The SVZ is a $1400 \mathrm{~km}$ long continuous volcanic arc, extending from $33.3^{\circ}$ to $46^{\circ} \mathrm{S}$ (Stern, 2007; Moreno and Gibbons, 2007). The study area is the south-eastern flank of Osorno volcano $\left(41.1054^{\circ} \mathrm{S}, 72.4961^{\circ} \mathrm{W}\right)$, beside Route $\mathrm{CH}-$ 255 (Fig. 1), which connects the villages of Ensenada (on the eastern side of Lake Llanquihue) and Petrohué (on Lake Todos los Santos).

The area has a total population of 44578 people with a density of 11 people per square kilometre. The topography makes Route CH-255 the only connection between Petrohué and Ensenada, and regular aerotransport is impossible except for a few flights by helicopters, unavailable for the local population. Therefore, Route $\mathrm{CH}-255$ becomes a critical infrastructure for local development. This has led to the route being called "El Solitario Pass" (Lonely Pass) Finally, note that the village of Petrohué has a population of 193 people, surpassing 3000 in summer. The village does not have the capacity for autonomous subsistence, depending on the food and services of Ensenada.

\subsection{Geological setting}

Osorno volcano is a mainly basaltic Pleistocene to Holocene composite volcano (Fig. 1). Its part of an SW-NE volcanic alignment along with three other volcanoes: La Picada, Puntiagudo and Cordón Cenizos (Moreno et al., 2010), oriented obliquely to the main volcanic arc and the Liquiñe-Ofqui Fault System (LOFS). The chain orientation suggests that the area is an active transtensional zone of the crust, with mafic magma extrusion during the Quaternary (Cembrano and Lara, 2009; Moreno et al., 2010). The surrounding area shows pre-LGM (Last Glacial Maximum) Pleistocene volcanic rocks including tuffs, breccias and lava originating from the northern zone of the volcano (Moreno et al., 1985).

Alluvial fans in Osorno volcano are composed of unselected sandy rich matrix polymictic gravels, organised in metres-thick banks. These form the current filling of the gul- 
lies on Osorno volcano, together with alluvial deposits generated by the re-working of moraine deposits and old lahar fans. Debris flows have also been recorded, triggered by snowmelt and intense rainfall in the zone (Moreno et al., 2010). Alluvial deposits exist that are associated with debris flows and rockfalls in the zone. The granulometry ranges from sand to gravel, and the deposits extend to the shore of Lake Todos los Santos (Garrido, 2015).

\subsection{Records of rainfall-induced landslides}

The zone has suffered recurrent debris flow events during periods of variable precipitation, so the factors which triggered these events are strictly unknown (Garrido et al., 2017, 2018). For example, debris flows and mudflows occurred on 2 June 2015, associated with a front of intense and prolonged precipitation over CH-255 (El Solitario Pass). These flows damaged five houses and four barns as well as destroying one water tank and some pipework of the second water tank of the drinking water supply network of the village of Petrohué (Garrido, 2015). On 8 January 2017, large debris flows occurred again in the eastern sector of the volcano's southern flank, during a front of intense precipitation. A total of $94 \mathrm{~mm}$ of precipitation in a period of $24 \mathrm{~h}$ was recorded in Ensenada, with the $0^{\circ}$ isotherm above $3000 \mathrm{~m}$ a.s.l. The Petrohué debris flow was an atypical event in that it occurred outside the season of intense precipitation; it caused serious material and economic damage to one of the most popular tourist attractions in southern Chile. The road was blocked in five different places, and tourists were cut off for several hours in the area of the Saltos de Petrohué (Garrido et al., 2017, 2018).

\section{Methodology}

The 2017 Petrohué event was studied to understand the factors which control the occurrence of debris flows in the Osorno volcano. We implement a methodological approach based on comprehensive numerical modelling constrained by field data and laboratory analysis (Fig. 2). We considered geomorphological factors that influenced debris flow generation in fieldwork, and we defined the release zones. The field results were used as border conditions in numerical modelling of the event by back analysis, taking flow heights recorded in technical reports and photographs to define zones of comparison.

\subsection{Field evidence}

The mechanisms which generated the 2017 Petrohue debris flow event were studied in the area, approaching by El Solitario Pass $\left(41.1943^{\circ} \mathrm{S}, 72.4759^{\circ} \mathrm{W}\right)$. Areas affected by the flow were identified and mapped in detail. In situ debris flow deposit analysis is critical to establishing a rheological model to be used. Specifically, the grain size distribution transported was assessed, indicating if the flow corresponds to a hyper- concentrated process or not. Hence, geomorphological characteristics were analysed, noting particularly slopes susceptible to movement in intense precipitation events. The geomorphological features were evaluated by measuring slopes and height with metric rules and qualitative analysis of depositional structures related to the debris flow.

Due to the extensiveness of the area, elevation and channel gradient data are derived from the two different digital elevation models (DEMs), SRTM and ASTER. Additional information regarding distance measurements such as side slopes, channel depth and the maximum width of the landslide was evaluated in the field using metric rulers. Specifically, the width of the landslide is identified and georeferenced using a handle GPS to constrain the numerical modelling results. On Route $\mathrm{CH}-255$, the final height of debris flows is established as $1.5 \mathrm{~m}$ by Garrido et al. (2017). Moreover, debris flow deposits identified in the field allowed the understanding of the rheology of these events (non-Newtonian flows). We evaluated debris flow initiation zones close to the volcano summit and the physical weathering of rock and soil. Scarps with potential rockfalls of unstable blocks were identified, measured and georeferenced. We established these scarps as initiation debris flow zones (or release zones) in the following numerical model. Finally, debris flow runout was estimated by measuring the channel distance between the liberation zone and the $\mathrm{CH}-255$ limit using navigation GPS.

Geomechanical properties of the mobilised material were characterised using geotechnical testing. Three unaltered geotechnical soil samples were extracted for a direct shear test (Fig. 1). The samples were extracted from a depth of $40 \mathrm{~cm}\left(41.1843^{\circ} \mathrm{S}, 72.4652^{\circ} \mathrm{W}\right)$ to avoid integrating possible organic material in each sample. Because the soil corresponds to a granular soil, we used a split cube (Table 1). The sampling probe was removed from unsaturated media without water table presence. The sample water content was determined by drying at a constant temperature of $60^{\circ} \mathrm{C}$ (ASTM, 2019). The geotechnical shear test was carried out by deforming a specimen at a constant controlled stress rate throughout the period of deformation based on the ASTM D3080/D3080M-11 standard (ASTM, 2020). The estimated values of the cohesion and internal friction angle were integrated into a database to be used during the back analysis phase.

\subsection{Debris flow modelling}

Representing debris flows is currently a challenge due to the possible changes in phase, which may occur during the process from generation to stabilisation. Therefore, the r.avaflow model was used to evaluate the fall of blocks in saturated and unsaturated zones and their subsequent evolution as nonNewtonian flow (Mergili et al., 2017, 2018b). Measurements of soil water content into the fall of blocks are not available. Therefore, various water content scenarios were carried out 


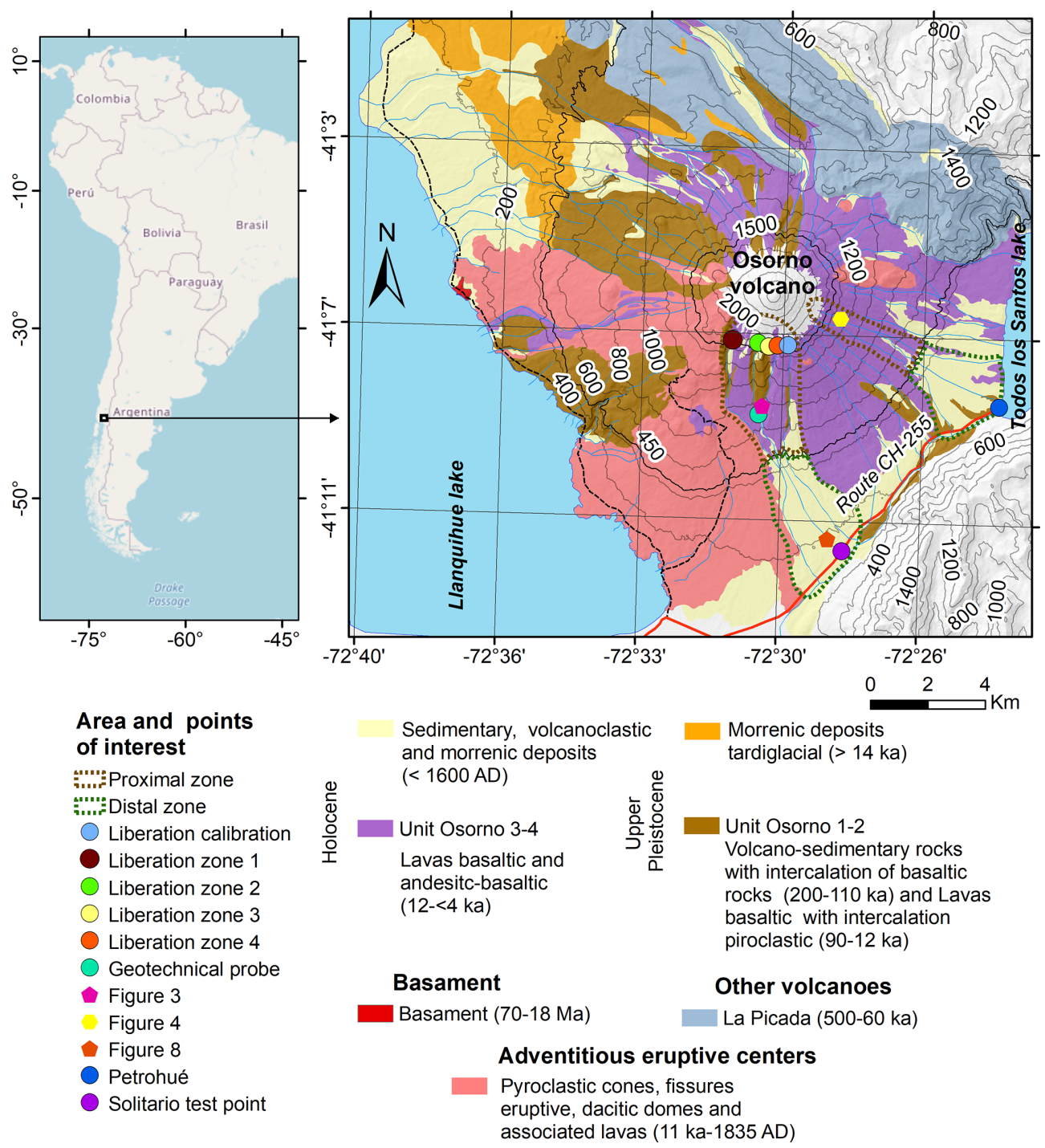

Figure 1. Geological map of Osorno volcano based on Moreno et al. (2010).

Table 1. Properties obtained by direct shear test. Geotechnical results incorporated into the r.avaflow model as constraints.

\begin{tabular}{|c|c|c|c|}
\hline \multicolumn{4}{|l|}{ Physical properties per test sample } \\
\hline Physical properties & Test sample 1 & Test sample 2 & Test sample 3 \\
\hline Water content $(\%)$ & 3.31 & 3.30 & 3.27 \\
\hline Natural density $\left(\mathrm{kg} \mathrm{m}^{-3}\right)$ & 1620 & 1560 & 1630 \\
\hline Density $\left(\mathrm{kg} \mathrm{m}^{-3}\right)$ & 1570 & 1510 & 1580 \\
\hline Density after consolidation $\left(\mathrm{kg} \mathrm{m}^{-3}\right)$ & 1670 & 1600 & 1640 \\
\hline Lateral displacement rate used $\left(\mathrm{mm} \mathrm{min}^{-1}\right)$ & 0.50 & 0.50 & 0.50 \\
\hline Lateral displacement achieved (\%) & 10.00 & 10.00 & 10.00 \\
\hline Maximum shear stress $\left(\mathrm{N} \mathrm{m}^{-2}\right)$ & 71589 & 50014 & 33343 \\
\hline Normal stress $\left(\mathrm{N} \mathrm{m}^{-2}\right)$ & 78453 & 39227 & 19613 \\
\hline
\end{tabular}




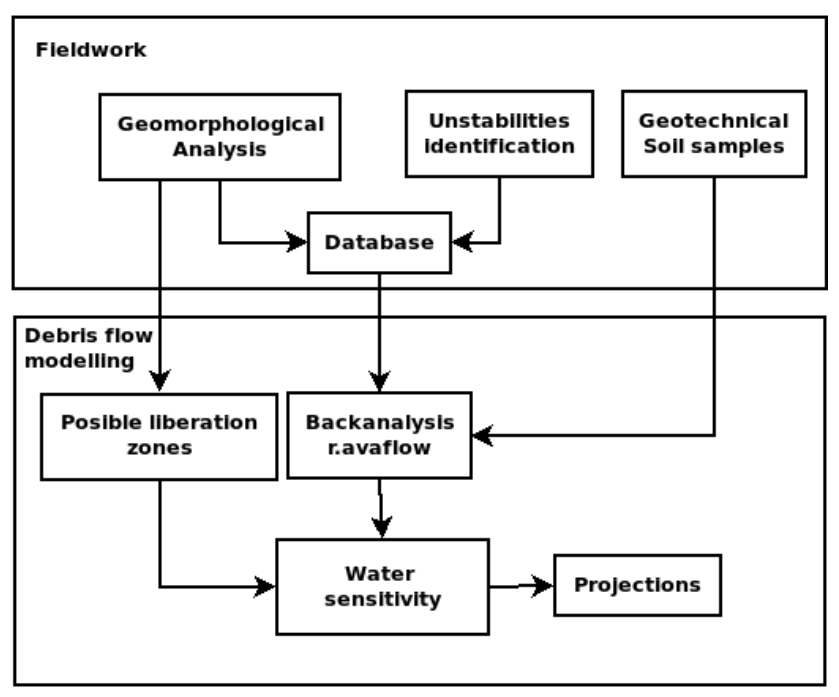

Figure 2. Short methodology.

\subsubsection{Back analysis}

The ravaflow model was applied by back analysis, taking as constraints the cohesion data and the angle of internal friction obtained from the undisturbed soil samples collected in the field (Fig. 1). The back analysis considered a final height of $1.5 \mathrm{~m}$ on Route $\mathrm{CH} 255$, according to reports of the National Geological and Mining Survey (SERNAGEOMIN in Spanish). Moreover, volumes of the liberation zone were integrated from the evidence collected in the field. The model used a two-phase parameterisation based on Pudasaini (2012). First, the solid phase corresponds to the lava and autobreccia fall; meanwhile, the second phase is associated with the debris flow generation under saturated and non-saturated water conditions. During the solid phase, a Mohr-Coulomb plasticity approach allowed it to be estimated for the stress. The fluid stress was modelled as a solidvolume-fraction-gradient-enhanced non-Newtonian viscous stress (Pudasaini, 2012; Mergili et al., 2017). Let $u_{\mathrm{s}}=$ $\left(u_{\mathrm{s}}, v_{\mathrm{s}}, w_{\mathrm{s}}\right), u_{\mathrm{f}}=\left(u_{\mathrm{f}}, v_{\mathrm{f}}, w_{\mathrm{f}}\right)$ and $\alpha_{\mathrm{f}}, \alpha_{\mathrm{f}}=\left(1-\alpha_{\mathrm{s}}\right)$ denote the velocities and volume fractions for the solid and the fluid constituents, denoted by the suffixes s and f, respectively, where $\eta_{\mathrm{f}}$ corresponds to the fluid viscosity with isotropic stress distribution, and $A\left(\alpha_{\mathrm{f}}\right)$ is called the mobility of the fluid at the interface. The average of the phase-averaged viscous-fluid stresses is modelled using non-Newtonian fluid rheology:

$$
\begin{aligned}
\tau_{\mathrm{f}} & =\eta_{\mathrm{f}}\left[\nabla \underline{\mathrm{u}}_{\mathrm{f}}+\left(\nabla \underline{u}_{\mathrm{f}}\right)^{t}\right]-\eta_{\mathrm{f}} \frac{A\left(\alpha_{\mathrm{f}}\right)}{\alpha_{\mathrm{f}}}\left[\left(\nabla \alpha_{\mathrm{s}}\right)\left(\underline{u_{\mathrm{f}}}-\underline{u_{\mathrm{s}}}\right)\right. \\
& \left.+\left(u_{\mathrm{f}}-u_{\mathrm{s}}\right)\left(\nabla \alpha_{\mathrm{s}}\right)\right] .
\end{aligned}
$$

The back analysis used a generalised interfacial momentum transfer that included viscous drag, buoyancy and virtual mass. Non-Newtonian viscous stress was based on Pudasaini and Mergili (2019), separating the solid and fine-solid volume fraction gradients, enhancing the apparent viscous stress estimation in the fluid phase. Parameters not measured in the field were established from similar works and data from the area of Villa Santa Lucía (Somos-Valenzuela et al., 2020; Table 2). We selected model parameters to the range proposed by Pudasaini (2012) for the simulation of debris flows. We compared height flow with the calibration point (Route $\mathrm{CH}$ 255), discarding unreasonable simulations.

Surface features such as slopes are important input data for debris flow modelling (Qin et al., 2013). DEM errors introduce uncertainty in terrain representation, leading to a poor estimation of the numerical solutions. Given the uncertainty in the DEM before the 2017 Petrohue event, two DEMs were used as references to assess the sensitivity of changes in elevation. The SRTM and ASTER models were used separately, with a spatial resolution of $30 \mathrm{~m}$ due to data availability limitations. The possible release zones or areas of origin of these debris flows were established from the geomorphological evidence found in the field. The results of the back analysis were compared with photographs provided by the Chilean Geology and Mining Survey (SERNAGEOMIN) based on El Solitario $\left(\sim 41.180^{\circ} \mathrm{S}, 72.462^{\circ} \mathrm{W}\right)$ to assess the performance of the models with different initial water contents.

\subsubsection{Sensitivity analysis}

A systematic study has been carried out to represent the debris flow. Mergili et al. (2018a) established that parameters with high sensitivity correspond to the basal friction angle, fluid friction coefficient and environmental drag coefficient. We used reference values previously considered in the zone (Somos-Valenzuela et al., 2020). Moreover, geotechnical laboratory tests allowed us to represent the friction angle and cohesion values adequately. Sources of uncertainty were attributed to surface representation and initial water content in the head of the block fall. A wide range of initial water content was considered, constrained by the geomorphological evidence at the site, to calibrate the model to observations in the field. Since the initial proportion of water when the hyper-concentrated flow was generated is unknown, we assumed a water content in the initial volume from $40 \%$ up to $70 \%$, considering the high porosity of the material involved. Hence, we calibrate the flow runout taking control points of the height of the flow measured on the main road minutes after the event. The percentual error was calculated using the height simulated with the measured height in $\mathrm{El}$ Solitario Pass. A percentual difference was used between the simulated value and the measured height divided by the measured height. We also assessed the quality of the simulations using possible release volumes based on field evidence. 
Table 2. Model parameters used in r.avaflow.

\begin{tabular}{llrl}
\hline Symbol & Parameter & Value & Units \\
\hline$\rho_{\mathrm{S}}$ & Solid material density & 2800 & $\mathrm{~kg} \mathrm{~m}^{-3}$ \\
$\rho_{\mathrm{f}}$ & Fluid material density & 1000 & $\mathrm{~kg} \mathrm{~m}^{-3}$ \\
$\phi$ & Internal friction angle & 32.4 & Degrees \\
$\delta$ & Basal friction angle & 6 & Degrees \\
$C$ & Virtual mass & 0.5 & - \\
$U_{\mathrm{T}}$ & Terminal velocity & 1 & $\mathrm{~m} \mathrm{~s}^{-1}$ \\
$P$ & Parameter for combination of solid- and fluid-like & 0.5 & - \\
& contributions to drag resistance & & \\
$R e_{\mathrm{p}}$ & Particle Reynolds number & 1 & - \\
$J$ & Exponent for drag & 1 & - \\
$N_{\mathrm{R}}$ & Quasi-Reynolds number & 4.5 & - \\
$N_{\mathrm{RA}}$ & Mobility number & 3 & - \\
$x$ & Viscous shearing coefficient for fluid & 0 & - \\
$\xi$ & Solid concentration distribution with depth & 0 & - \\
$C_{\mathrm{AD}}$ & Ambient drag coefficient & 0,02 & - \\
$C_{\mathrm{E}}$ & Entrainment coefficient & -6.69 & $\mathrm{~kg}$ \\
$C_{\mathrm{FF}}$ & Fluid friction coefficient & 0.001 & \\
\hline
\end{tabular}

\subsubsection{Projections}

Finally, possible scenarios evaluating the impact of new debris flows in the area were analysed. Therein, we defined new unstable release zones identified visually in the field. We identify areas with intense rain erosion, hanging blocks or fractured rocks. This enabled us to estimate the potential volume transported and thus to understand the impact of different debris flows generated in zones that were very close together but with release at different altitudes.

\section{Results}

The conditions that generate debris flows were evaluated in an active volcanic zone, with reference to the 2017 Petrohué event. Information collected in the field was assessed and compared with numerical modelling using back analysis with r.avaflow.

\subsection{Field evidence}

The debris flow in the distal zone is characterised by poorly sorted volcanic material. The deposited material is supported by a medium-coarse sand matrix $(2 \mathrm{~mm})$ along with $>1 \mathrm{~m}$ diameter blocks. The mode of the clasts in the sandy matrix varies between 3 and $10 \mathrm{~cm}$, being consistent with previous results (Garrido et al., 2017). Moreover, lateral erosion after the debris flow shows a highly energetic process. Geotechnical measurements showed low unit weight (Table 2), suggesting that the thickness of the flow is moderated. This favours a faster movement, increasing lateral erosion according to field results (Shu et al., 2018). The lahar deposits show granulometric differences, with strong grad- uation from the fracture zone (proximal zone) to the final deposition zone (distal zone). From $400 \mathrm{~m}$ a.s.l., volcanic deposits alternate with autobrecciated lava flows (Fig. 3). The walls are up to $20 \mathrm{~m}$ high with high stratification and different grain size. A pronounced difference in competence was observed between the volcanic deposits and the autobrecciated lava flows, which facilitates differential erosion and planes of weakness (Fig. 4).

Field evidence showed that debris flows are generated by the fracture of basaltic lava over volcanic deposits in the high-altitude zone of the study area. Rockfalls occurring above $1500 \mathrm{~m}$ a.s.l. were identified (Figs. 1 and 4). This zone presents numerous scarps with pronounced slopes overhanging fluvial drain channels (Fig. 3). The remains of the debris flow identified in the field are associated with transported blocks of basaltic lava and primary lahar deposits.

The incision is favoured by the presence of very thick lahar deposits (Fig. 3), which facilitate the removal and contribution of material to the main channel. A sequence of lahar deposits was observed, overlain by lava flows in blocks up to $1.5 \mathrm{~m}$ thick. These occur in regular sequences, leaving alternate levels of erosion and hanging blocks, facilitating the collapse of the lava levels, and generating rockfalls. The material is characterised by lava with base autobrecciation no more than $1 \mathrm{~m}$ thick (Fig. 3). The autobrecciated zone is also heavily weathered (Fig. 4); as a result, it can be easily removed, exposing the centre of the lava flow. The lava flow forms a hanging block that can easily fracture and break off. There is evidence of broken-off blocks associated with the central part of the lava flow due to the instability of the base autobrecciation, with dimensions of up to $2 \mathrm{~m}$. The blocks fracture continuously in the lava runs perpendicular to the slope of the main channel where these debris flows occur. 
This breaking-off of material due to weathering contributes to the main channel, generating powerful debris flows as evidenced by the deposits further down the slope as a consequence of the continuous rockfalls. The intermediate zone has narrow drainage channels and an increase in the incision to a depth of around $15 \mathrm{~m}$ (Fig. 3).

\subsection{Debris flow modelling}

To understand the scope of the runout generated in the release zones of material recognised in the field, the flow was modelled in r.avaflow. Different initial water content into the simulations and DEM differences allowed the understanding of the uncertainty in the main initial input. The results of the back analysis, restricted by geotechnical soil data, showed that the model that presented the smallest mean error was the simulation using the SRTM DEM and $70 \%$ water content ( $5 \%$ error). The results show that in both simulations, the flow covers a large part of Route $\mathrm{CH}-255$, to a $1.59 \mathrm{~m}$ depth with the SRTM DEM and $1.58 \mathrm{~m}$ depth with the ASTER DEM (Fig. 5). Our results indicate that the ASTER DEM presented a larger underestimation of the height of $-25 \%$ with a water content of $65 \%$. With a water content of $40 \%$, the ASTER DEM produces an overestimation of $63 \%$ against the value measured. These results suggest that the initial quantity of water during the collapse has a large influence on the area affected.

The area affected by the debris flow was estimated at between 7.5 and $7.8 \times 10^{6} \mathrm{~m}^{2}$ by the ASTER DEM and between 8.3 and $8.6 \times 10^{6} \mathrm{~m}^{2}$ by the SRTM DEM (Fig. 5a). Simulations using the SRTM DEM produced a variation in the flow to the south, increasing the impact on Route $\mathrm{CH}-255$. These results had differences with the simulations using the ASTER DEM, which showed the flow towards the north (Fig. 6). The maximum height was calculated at between 5.55 and $6.74 \mathrm{~m}$ by the ASTER DEM and between 6.33 and $7.69 \mathrm{~m}$ by the SRTM DEM. A progressive increase in the maximum height as the percentage of water in the release zone increased was noted in the simulations. The SRTM DEM presented greater heights than the ASTER DEM in all the simulations. The major debris flow height is reached when the initial volume has $70 \%$ of the water in both DEMs. Finally, all the simulations reached populated zones, regardless of the DEM used. The maximum height with the SRTM DEM is $1.87 \mathrm{~m}$ with a water content of $40 \%$ of the initial water content, while with the ASTER DEM, it is $2.13 \mathrm{~m}$ with a water content of $60 \%$. The greatest heights are concentrated with a water content of $50 \%-60 \%$ of the total material released.

In addition to the zone identified as the source of the Petrohue event of 2017, three zones with unstable autobrecciated lava were catalogued as possible debris flow generation zones (Figs. 1 and 4). The information collected in the field showed that the gullies in these zones are severely weakened, so debris flows produced by rockfalls can be expected imminently. Additional release zones to those in r.avaflow were estimated with calibration based on the parameters of the back analysis model. Our results indicate that the area potentially affected by the debris flow varies between 3.1 and $3.8 \times 10^{6} \mathrm{~m}^{2}$ using the ASTER DEM and between 1.3 and $4.4 \times 10^{6} \mathrm{~m}^{2}$ using the SRTM DEM (Fig. 7). The SRTM DEM produces the largest area affected, with $60 \%$ water content in the initial volume released and the ASTER DEM with $70 \%$.

According to the back analysis, a rockfall with $50 \%$ water content is capable of transporting a potential volume of $138628 \mathrm{~m}^{3}$; the potential with $70 \%$ water is $148830 \mathrm{~m}^{3}$. According to the SRTM DEM, the potential volume with $50 \%$ water content is $32039 \mathrm{~m}^{3}$, increasing to $177399 \mathrm{~m}^{3}$ with $70 \%$ water. In this case, the greatest volume is generated when the proportion of water is equal to $70 \%$ of the volume initially released, and the highest value is given by the SRTM DEM simulation. The lowest value is obtained with a water content of $50 \%$ using the SRTM DEM. Finally, the maximum height for the SRTM DEM is $0.76 \mathrm{~m}$, when the water content is $70 \%$ of the volume released. In this simulation in the ASTER DEM, the debris flow would not reach Route $\mathrm{CH}-255$ (Fig. 7). Our results indicate that the flow released from zone 2 with $60 \%$ water content will reach a minimum height of $1.82 \mathrm{~m}$ in populated zones. Likewise, there are cases in which the debris flow will not necessarily reach the populated zones, suggesting that events of this type are not always recorded.

Finally, our results indicate the existence of events that will not generate debris flows even if there is a fall of lava blocks in the channel. This can be seen in zone 1, identified by the evidence collected in the field as an area in which debris flows are generated. On the other hand, a hypothetical scenario of a debris flow generated in zone 2 could lead to debris flows with larger volumes than those observed in previous events (Fig. 7). Likewise, it can generate greater flow heights than values recorded to date, leading to more catastrophic events in populated zones. This risk has not been considered to date and needs to be assessed with care.

\section{Analysis and discussion}

\subsection{Field evidence}

The geomorphology of the Osorno volcano is characterised by the alternation of basaltic lava flows overlain by large volcanic deposits (Fig. 3). The fractures identified in the lava flows were probably generated by gravitational effects. Water can then enter the rock and soil fractures, making them more likely to break off and transporting the material in the form of debris flow. Conditions are therefore favourable for chain processes culminating in debris flows when the soil is saturated by high-altitude rainfall. Erosion of the deposits exposes the lava flows; material breaks away and is transported by gravity and/or swept down by the force of the water. Fur- 


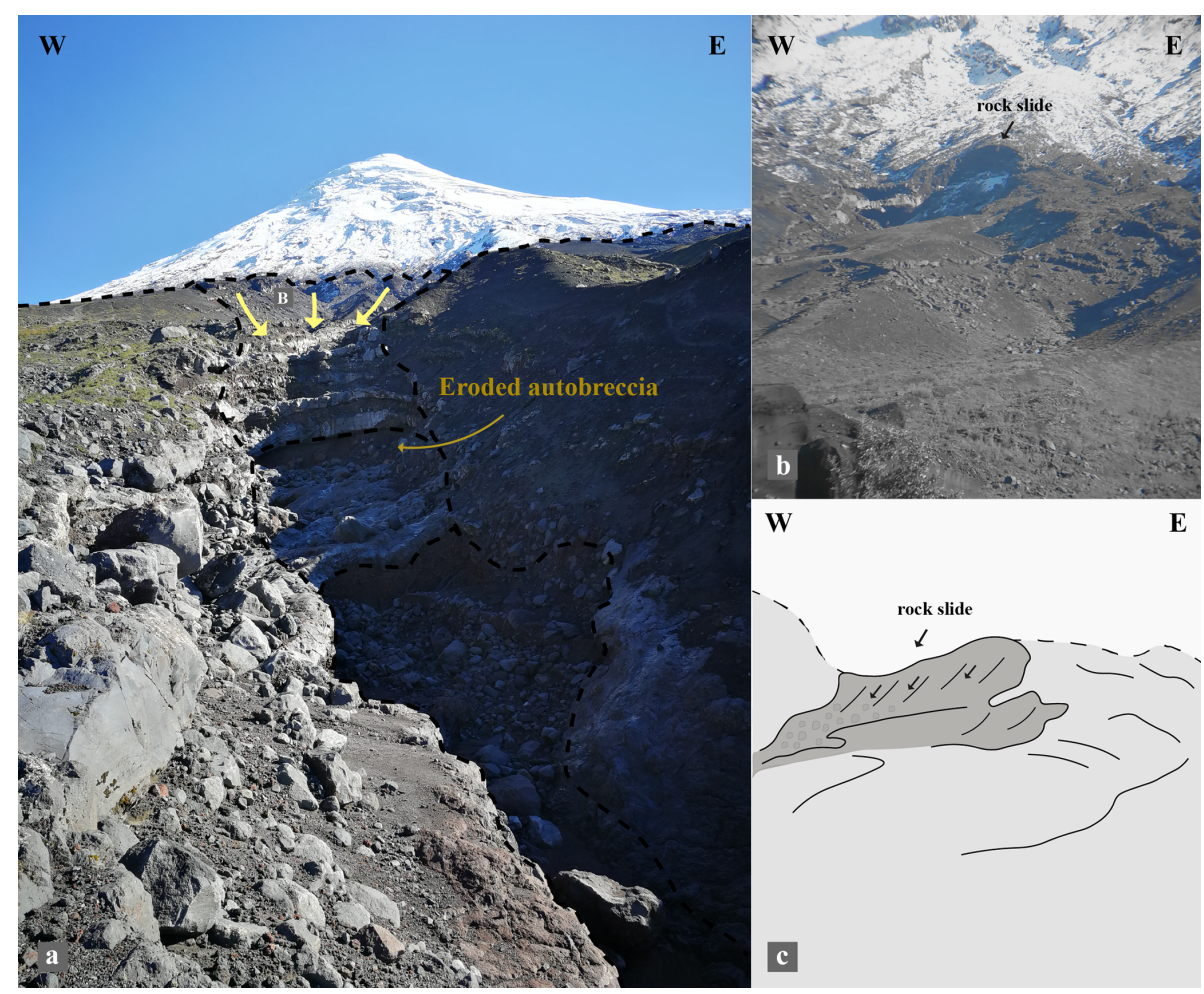

Figure 3. A $15 \mathrm{~m}$ high scarp showing the stratigraphy of the volcano at this point, composed of alternating volcanic and lava deposits.

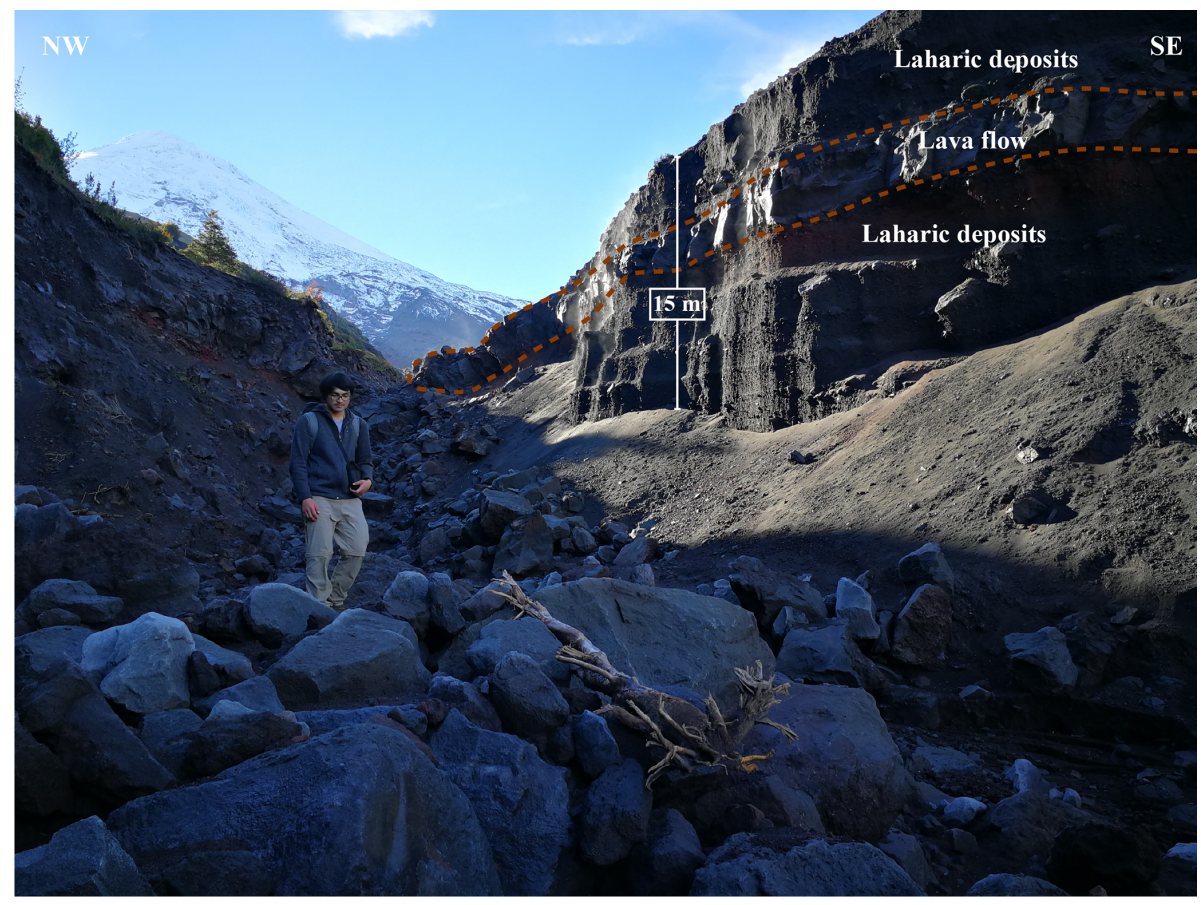

Figure 4. Set of scarps at approximately $1500 \mathrm{~m}$ a.s.l.; the base breccia of the lava flows is heavily eroded. 

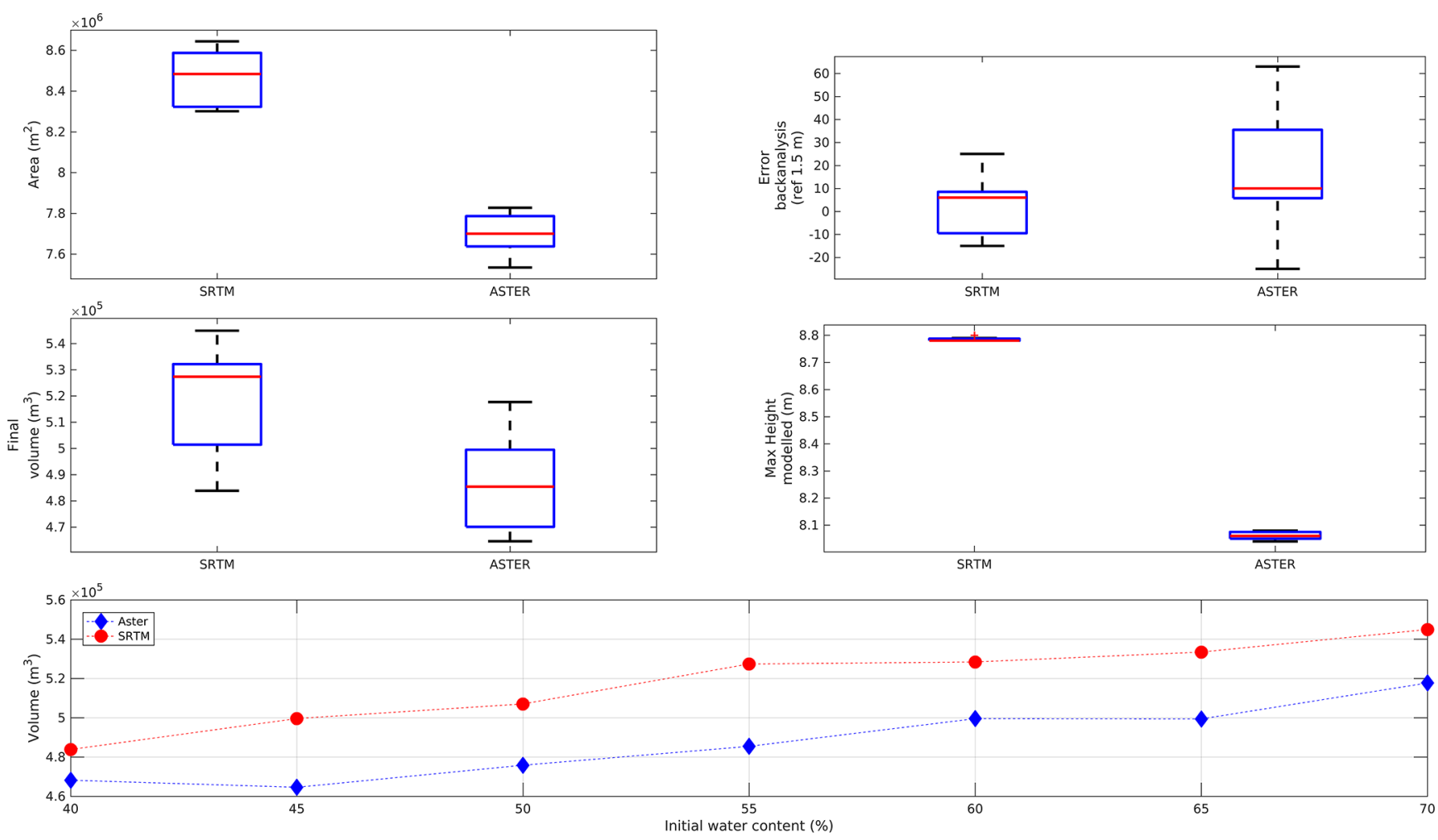

Figure 5. Back analysis results.

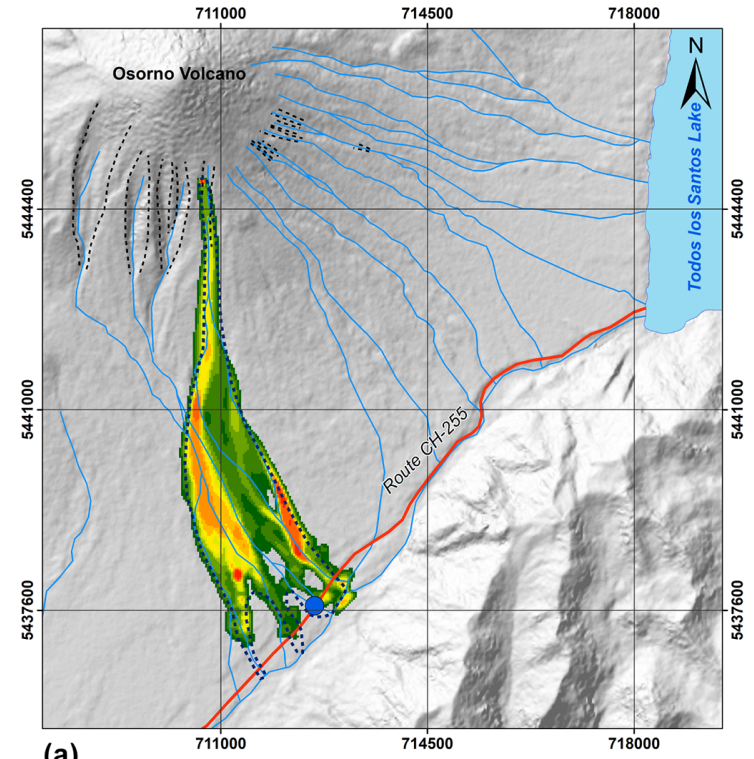

(a)
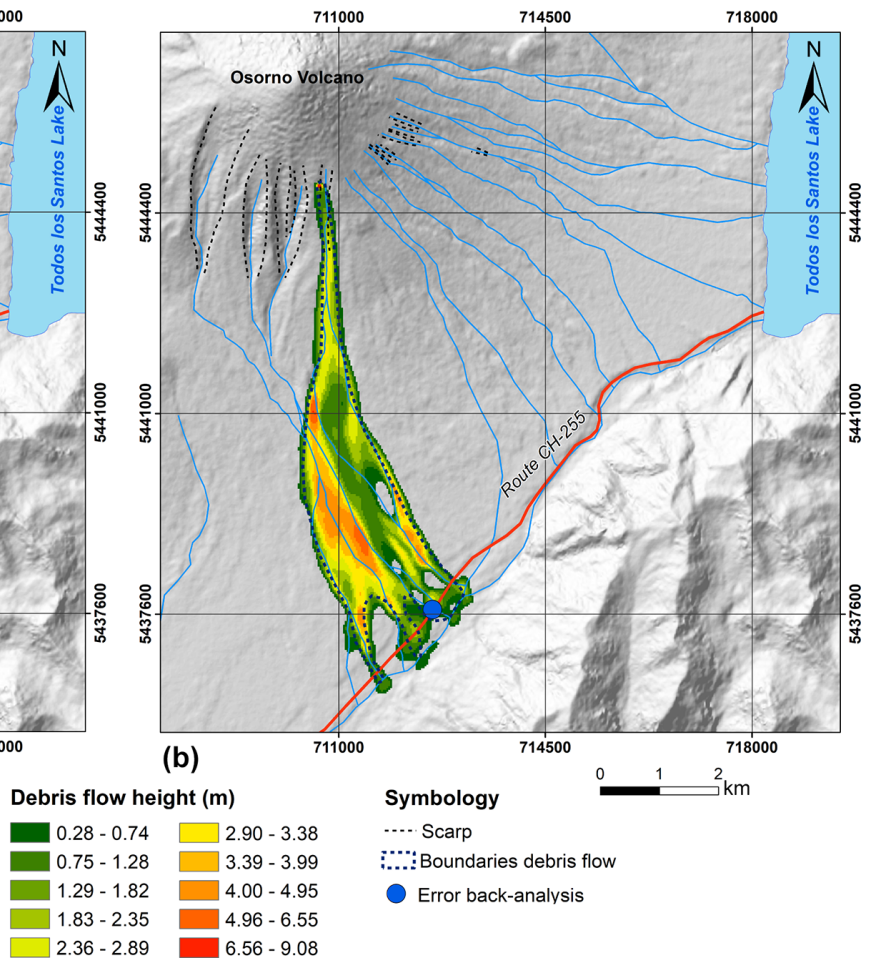

(b)

$$
\begin{aligned}
& \text { Symbology } \\
& \cdots \cdot . \text { Scarp } \\
& \text { …: Boundaries debris flow } \\
& \text { Error back-analysis }
\end{aligned}
$$

Figure 6. Simulation in the El Solitario sector, taking the release zone from the results obtained in the field. (a) Model with $60 \%$ water content in the ASTER DEM. (b) Model with $60 \%$ water content in the SRTM DEM. 

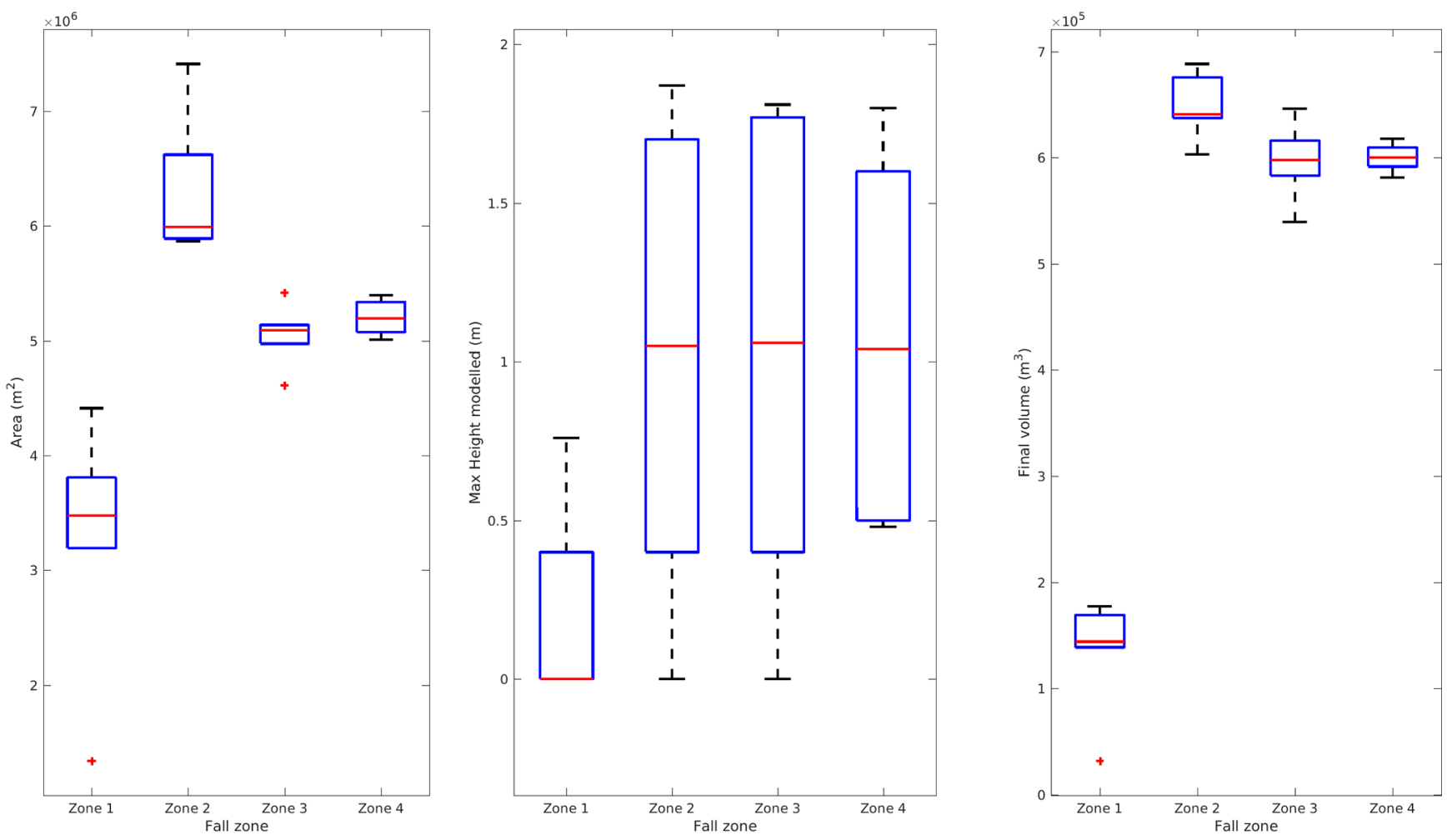

Figure 7. Impact of different debris flows.

thermore, the autobrecciation of the lava flows increases the instability of the rock faces in the release zones due to the high porosity of the material (Vezzoli et al., 2017; Schaefer et al., 2018).

The evidence collected in the field showed a heterogeneous distribution of lava and slopes close to the debris flow release zones. In this way, the magnitude and force of the landslide processes may be affected by the spatial distribution of volcanic products, principally lava flows. The results show that above $600 \mathrm{~m}$ a.s.l., there are many exposed lava layers at the base of the principal fluvial channels. A bedrock channel could increase the velocity of the flow in comparison to an alluvial-type channel. This characteristic suggests that the base could act as a sliding surface for the material (Dufresne et al., 2019), which is very common in stratovolcanoes in the southern Andes. It could be a smooth surface with lower friction, especially under rainy conditions. This could have a critical influence on the velocity and acceleration of the flow from the higher reaches of the edifice. Lavigne and Suwa (2004), Sheridan et al. (2005), and Aaron and Hungr (2016) suggest that the dynamic of debris flows depends upon the friction of the base surface. Having said this, the distribution of the lava and its autobrecciation play an important role in the generation of landslides, rockfalls and debris flows in the study zone (Fig. 8).

\subsection{Debris flow modelling}

Our results represented the dynamic of the 2017 Petrohué debris flow with variable errors in the back analysis. Our models were consistent with results obtained in the field, showing a strong influence on the initial water content. The simulations present high sensitivity to the water content previous to the generation of the event; all the simulations in which the water content in the release zone was higher than $45 \%$ reached populated zones. The calibration parameters played an important role in the sensitivity of the numerical model. In the present study, the drag coefficient was established at 0.020, based on Zwinger et al. (2003) and Oyarzún (2019); this value was adopted due to the degree of optimisation in the back analysis. A larger or smaller coefficient could produce large deviations in the final height and direction of the flow (Mergili et al., 2018a). The angle of internal friction was determined by a geotechnical study. However, the heterogeneity of the zone could produce substantial changes in $\varphi$, so this value must be assessed with great care in future cases. This introduces great uncertainty into the models due to the existence of an imminent bias in the results. It is clear from our results that the use of a DEM introduces a bias in the modelling, which may be directly linked with the methodology by which each product is created and the date of acquisition (e.g. Kääb et al., 2005; Bühler et al., 2011). It must be remembered that processes may occur which pro- 


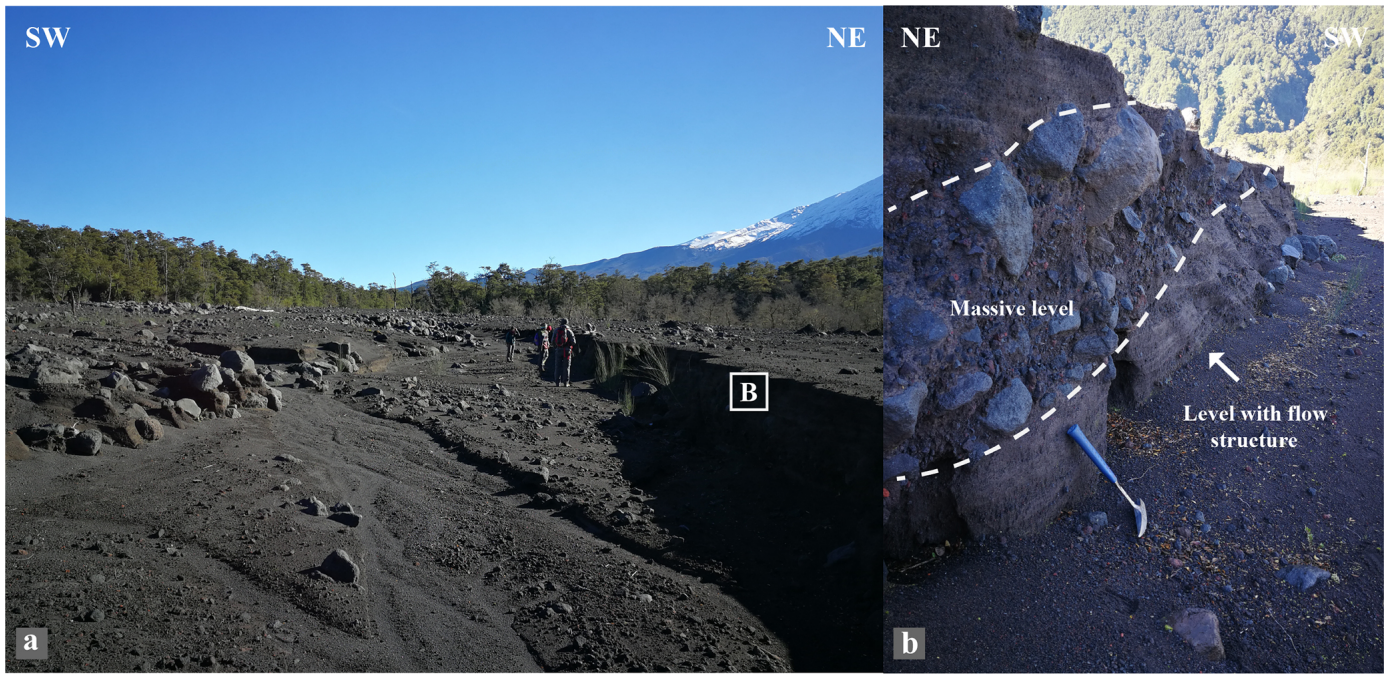

Figure 8. (a) Distal zone in an alluvial deposit in the El Solitario sector. (b) Alluvial deposit with thickness of $1.2 \mathrm{~m}$; the base level presents flow structures with fluvial erosion.

duce changes in the relief that the DEM is unable to capture due to low spatial resolution (Fig. 8a and b). Alganci et al. (2018) report that the SRTM has better vertical accuracy $(8.5 \mathrm{~m})$ than ASTER $(16 \mathrm{~m})$. Vertical uncertainty provides wrong flow routing values, overestimating the final height in some cases. Therefore, the DEM product could introduce an additional uncertainty which must be analysed carefully during calibration and interpretation. Nonetheless, back analysis allows us to estimate variations in the volumes transported and their extreme values, with variation within the same order of magnitude (Fig. 6).

The results show that the scope of the debris flow is proportional to the initial water content. Thus the water content available during the collapse of material at the $1500 \mathrm{~m}$ contour allows events to occur which will reach populated zones. Our results show that debris flows are dangerous if the collapse happens with saturation over $50 \%$. We propose that the presence of water in the release zone is explained by local hydrometeorological conditions, i.e. rainfall at high altitude; this is consistent with similar events at Villa Santa Lucía (Garrido et al., 2018; Somos-Valenzuela et al., 2020).

The differences between the initial and final volumes suggest the incorporation of material into the debris flow due to the erosion, which causes movement of the flow (Fig. 9). This is supported by evidence in the field, which showed that movable material is available between the distal and proximal zones (Fig. 8b). Retreating scarps were observed, which continuously add material to the drainage networks, and this material is available when debris flows occur. Our field results indicate that the largest volume of the material comes from volcanic deposits (Fig. 8a).

Finally, water-rich mass flows are distinguished by material type, water content, the presence of excess pore pressure or liquefaction at the source (Calhoun and Clague, 2018).
We controlled possible sources of uncertainty such as lithology and topography through a terrain analysis that allowed us to reduce degrees of freedom. Therefore, the initial water content becomes an important independent variable due to the unknown value during the main event. The gap of soil moisture stations close to the liberation zone does not allow us to constrain the numerical solution with precise detail. Our results show debris flow generation over $50 \%$ of initial water content. The final volume variation in the debris flow varies between 4.8 and $5.6 \times 10^{5} \mathrm{~m}^{3}$. The SRTM DEM showed small errors in comparison to ASTER, so we establish that the volume estimated from the SRTM is more suitable for our case. Moreover, the SRTM showed more area affected by the debris flow in comparison to ASTER. We propose that the use of an SRTM scenario corresponds to an accurate solution considering lesser error and conservative solutions for future debris flow events. However, we do not establish preliminary conditions for soil liquefaction. In the future, this issue will need to be addressed carefully to improve our understanding of the flow-type landslide in volcanic environments.

\subsection{Future implications}

Our projections indicate that the danger to populated areas is strongly dependent on the release zone of debris flows (Fig. 7). This suggests that debris flows may repeatedly occur, which are not observed because they are remote from populated areas, increasing the structural destabilisation of the volcano in the long term. The release volumes calculated in the present study were defined according to the current stability conditions observed in the field; however, more intense precipitation could lead to more significant rainfall erosion of transportable material (Fig. 8b), favouring increasingly vio- 


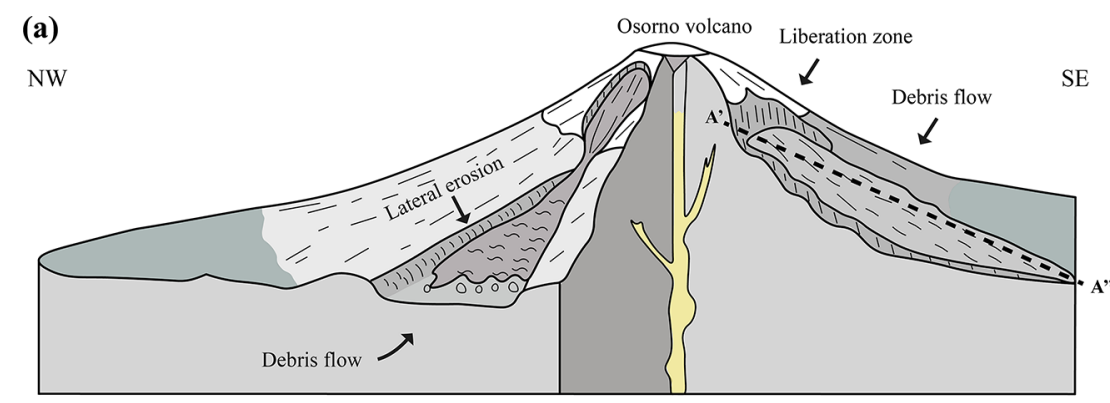

(b)

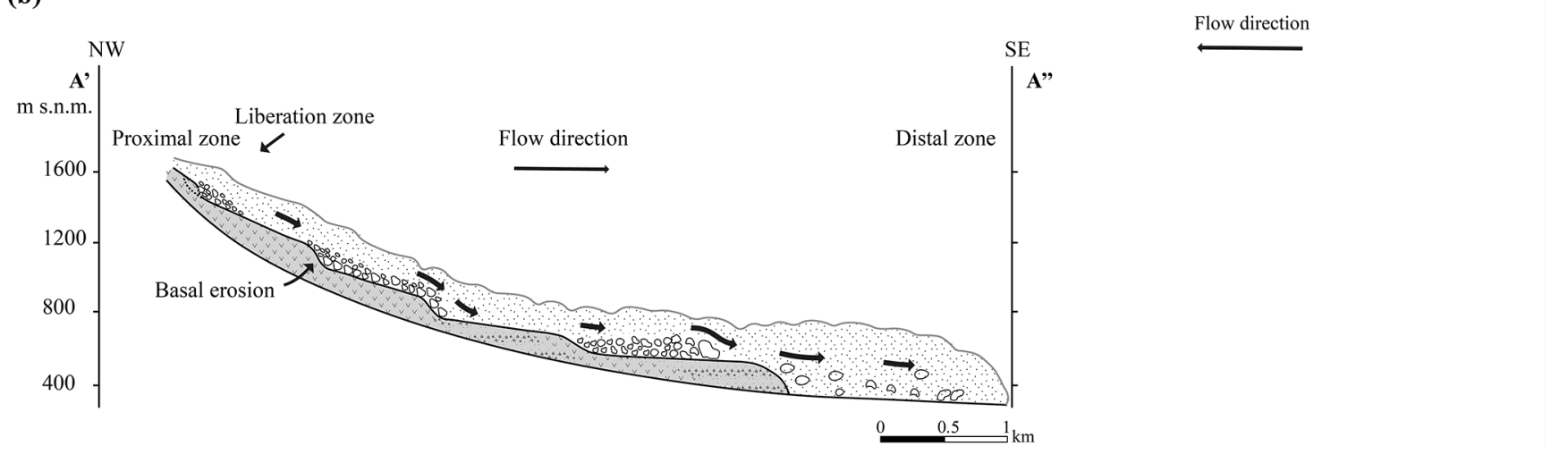

Figure 9. Conceptual model of chain processes in Osorno volcano.

lent debris flows. Such scenarios require the appropriate authorities to propose road design projects as a matter of urgency to evacuate the flows quickly and efficiently. This will improve the mitigation efforts to prevent the population from becoming cut off from the rest of the country. Finally, the geomorphology of the Osorno volcano is not unique in the southern Andes. For example, Villarrica and Llaima volcanoes show similar conditions to Osorno. We thus have firm grounds for assuming that unexpected debris flows could occur elsewhere in southern Chile, with the difference that these volcanoes are in more densely populated zones, exposing the population to even more danger.

\section{Conclusion}

The 2017 Petrohué event was studied by back analysis to understand the impact of debris flows occurring on active volcanoes in the southern Andes. We used comprehensive in situ data to constrain a numerical model for understanding the debris flow event. We evaluate the liberation zone for Osorno volcano, showing that debris flows occur due to the collapse of autobrecciated lava flows above $1500 \mathrm{~m}$ a.s.l. for the first time (Fig. 9a). Geomorphological in situ data determined that the debris flow was a combination of factors such as fluvial erosion and the composition of the volcano, both of which together led to a loss of stability (Fig. 9b). The succession of volcanic deposits and autobrecciated lava flows gen- erates conditions for the development of debris flows. Geomorphological evidence has shown that block falls and slips occurring mainly above $1500 \mathrm{~m}$ a.s.l. become debris flows, increasing the volume transported to the base of the volcano (Fig. 9c).

Simulations in ravaflow showed that the debris flow volume varies between 464564 and $544903 \mathrm{~m}^{3}$, depending on the amount of water available. Moreover, debris flow from only $45 \%$ of water content may reach the populated areas. Hence, the water available is critical in the rockfall zone in the first steps of the debris flow. Debris flow projections indicate that the final volume generated could vary between 32039 and $688142 \mathrm{~m}^{3}$ depending on the initial water content and generation zone in the volcano. Small debris flow volumes projected suggest that it could be generated continuously without reaching populated areas. Moreover, constant erosive processes could cause larger rockfalls and slips, causing more catastrophic events in the future. Therefore, the Osorno volcano needs to be taken into account as a hotspot for debris flow monitoring.

Finally, our results report for the first time a case of debris flow on a stratovolcano in the southern Andes from its generation, using data collection in situ and modelling with sensitivity analysis using a two-phase model. Our conclusion is to urge the scientific community to focus efforts on generating scenarios for debris flows in the stratovolcanoes of the southern Andes. The population density around Osorno 
volcano is low but receives a high number of tourists every year. However, the areas of stratovolcanoes like Villarrica and Calbuco contain higher population densities, and these volcanoes must not be ignored in future territorial plans. The present study shows evidence that the debris flows identified are recurrent events, even though they do not always reach populated areas. Our results show that this threat is inherent to volcanic activity, so any future risk analysis must consider debris flows. This will allow better risk management in nearby population centres and a safer coexistence with the volcanic structures of the southern Andes.

Code availability. The code is available at https://www. landslidemodels.org/r.avaflow/ developed by Mergili and $\mathrm{Pu}-$ dasaini (2014-2021).

Data availability. The datasets used in this study are available in the paper. The ALOS-PALSAR DEM is publicly accessible at https://search.asf.alaska.edu/\#/?dataset=ALOS (last access: 30 September 2021). Additional information about the information or datasets can be obtained from Ivo Janos Fustos-Toribio, ivo.fustos@ufrontera.cl.

Supplement. The supplement related to this article is available online at: https://doi.org/10.5194/nhess-21-3015-2021-supplement.

Author contributions. IJFT and BMV contributed to the conceptualisation and methodology of the research and performed the formal analysis, visualisation and validation. IJFT and MSV were involved in the funding and supervision of the paper. IJFT and PMY contributed with the supervision, review and editing of the paper. RMR, IRA and NC provided input in terms of methodology and the review and editing of the paper.

Competing interests. The authors declare that they have no conflict of interest.

Disclaimer. Publisher's note: Copernicus Publications remains neutral with regard to jurisdictional claims in published maps and institutional affiliations.

Acknowledgements. This was made possible thanks to the "Agencia Nacional de Investigación y Desarrollo (ANID)" of the Chilean government (grant no. PII180008) and the "Fondecyt Iniciación" programme (grant no. 11180500). We acknowledge the Dirección de Investigación of the University of La Frontera for their English editing support.We acknowledgements to the reviewers for their exhaustive review and constructive comments that allow improving this study significantly.
We appreciate the support of Mauricio Hermosilla, Gonzalo Maragaño and Elizabet Lizama for their support in fieldwork and geotechnical analysis.

Financial support. This research has been supported by ANID (grant nos. PII180008 and Fondecyt 11180500).

Review statement. This paper was edited by Giovanni Macedonio and reviewed by Roberto J. Marin and one anonymous referee.

\section{References}

Aaron, J. and Hungr, O.: Dynamic analysis of an extraordinarily mobile rock avalanche in the Northwest Territories, Canada, Can. Geotech. J., 53, 899-908, https://doi.org/10.1139/cgj-20150371, 2016.

Aguilar, G., Carretier, S., Regard, V., Vassallo, R., Riquelme, R., and Martinod, J.: Grain size-dependent ${ }^{10} \mathrm{Be}$ concentrations in alluvial stream sediment of the Huasco Valley, a semi-arid Andes region, Quaternary Geochronol., 19, 163-172, https://doi.org/10.1016/j.quageo.2013.01.011, 2014.

Alganci, U., Besol, B., and Sertel, E.: Accuracy Assessment of Different Digital Surface Models, ISPRS Int. J. Geo.-Inf., 7, 114, https://doi.org/10.3390/ijgi7030114, 2018.

Alimohammadlou, Y., Najafi, A., and Yalcin, A.: Landslide process and impacts: A proposed classification method, CATENA, 104, 219-232, https://doi.org/10.1016/j.catena.2012.11.013, 2013.

ASTM: D2216-19, Standard Test Methods for Laboratory Determination of Water (Moisture) Content of Soil and Rock by Mass, ASTM International, West Conshohocken, PA, 2019, https://doi.org/10.1520/D2216-19, 2019.

ASTM: D3080/D3080M-11: Standard Test Method for Direct Shear Test of Soils Under Consolidated Drained Conditions (Withdrawn 2020), ASTM International, West Conshohocken, PA, 2011, https://doi.org/10.1520/d3080_d3080m-11, 2020.

Bühler, Y., Christen, M., Kowalski, J., and Bartelt, P.: Sensitivity of snow avalanche simulations to digital elevation model quality and resolution, Ann. Glaciol., 52, 72-80, https://doi.org/10.3189/172756411797252121, 2011.

Bueechi, E., Klimeš, J., Frey, H., Huggel, C., Strozzi, T., and Cochachin, A.: Regional-scale landslide susceptibility modelling in the Cordillera Blanca, Peru - a comparison of different approaches, Landslides, 16, 395-407, https://doi.org/10.1007/s10346-018-1090-1, 2018.

Calhoun, N. C. and Clague, J. J.: Distinguishing between debris flows and hyperconcentrated flows: an example from the eastern Swiss Alps, Earth Surf. Proc. Land., 43, 1280-1294, https://doi.org/10.1002/esp.4313, 2018.

Cembrano, J. and Lara, L.: The link between volcanism and tectonics in the southern volcanic zone of the Chilean Andes: A review, Tectonophysics, 471, 96-113, https://doi.org/10.1016/j.tecto.2009.02.038, 2009.

Dufresne, A., Wolken, G. J., Hibert, C., Bessette-Kirton, E. K., Coe, J. A., Geertsema, M., and Ekström, G.: The 2016 Lamplugh rock avalanche, Alaska: deposit structures and emplacement dynam- 
ics, Landslides, 16, 2301-2319, https://doi.org/10.1007/s10346019-01225-4, 2019.

Evans, S. G., Bishop, N. F., Fidel Smoll, L., Valderrama Murillo, P., Delaney, K. B., and Oliver-Smith, A.: A reexamination of the mechanism and human impact of catastrophic mass flows originating on Nevado Huascarán, Cordillera Blanca, Peru in 1962 and 1970, Eng. Geol., 108, 96-118, https://doi.org/10.1016/j.enggeo.2009.06.020, 2009.

Fustos, I., Abarca-del-Rio, R., Moreno-Yaeger, P., and SomosValenzuela, M.: Rainfall-Induced Landslides forecast using local precipitation and global climate indexes, Nat. Hazards, 102, 115-131, https://doi.org/10.1007/s11069-020-03913-0, 2020.

García-Delgado, H., Machuca, S., and Medina, E.: Dynamic and geomorphic characterizations of the Mocoa debris flow (March 31, 2017, Putumayo Department, southern Colombia), Landslides, 16, 597-609, https://doi.org/10.1007/s10346-018-011213, 2019.

Garrido, N.: Deslizamientos y flujos de detritos en Petrohué, Sierra Santo Domingo, naciente río Petrohué ladera sur. 02.06.2015. Servicio Nacional de Geología y Minería, Informe Técnico, 11 pp., 2015.

Garrido, N., Mella, M., Sepúlveda, V., Duhart, P., and Moreno, H.: Efectos geológicos de los flujos de detritos ruta $\mathrm{CH}-225$ entre Ensenada y Petrohué, 08 de enero 2017, región de Los Lagos (INF-X-05.2017) [informe inédito], Puerto Varas: Sernageomin, 2017, 12, 2017.

Garrido, N., Sepúlveda, V., Duhart, P.: Catastro de remociones en masa de la Provincia de Llanquihue, Región de Los Lagos (INF-Los Lagos-10.2018) [informe inédito], Puerto Varas, Sernageomin, 2018.

INE: ENCUESTA MENSUAL DE ALOJAMIENTO TURÍSTICO, AÑO 2017, Technical report, available at: https://www.ine.cl/docs/default-source/ actividad-del-turismo/publicaciones-y-anuarios/informe-anual/ informe-anual-emat-2017.pdf (last access: 12 June 2020), 2018.

Jakob, M., Hungr, O., and Jakob, D. M.: Debris-flow Hazards and Related Phenomena, Springer, Berlin, Heidelberg, 2005.

Johnson, J. B. and Palma, J. L.: Lahar infrasound associated with Volcán Villarrica's 3 March 2015 eruption, Geophys. Res. Lett., 42, 6324-6331, https://doi.org/10.1002/2015gl065024, 2015.

Kääb, A., Huggel, C., Fischer, L., Guex, S., Paul, F., Roer, I., Salzmann, N., Schlaefli, S., Schmutz, K., Schneider, D., Strozzi, T., and Weidmann, Y.: Remote sensing of glacier- and permafrostrelated hazards in high mountains: an overview, Nat. Hazards Earth Syst. Sci., 5, 527-554, https://doi.org/10.5194/nhess-5527-2005, 2005.

Korup, O., Seidemann, J., and Mohr, C. H.: Increased landslide activity on forested hillslopes following two recent volcanic eruptions in Chile, Nat. Geosci., 12, 284-289, https://doi.org/10.1038/s41561-019-0315-9, 2019.

Lavigne, F. and Suwa, H.: Contrasts between debris flows, hyperconcentrated flows and stream flows at a channel of Mount Semeru, East Java, Indonesia, Geomorphology, 61, 41-58, https://doi.org/10.1016/j.geomorph.2003.11.005, 2004.

Major, J. J., Bertin, D., Pierson, T. C., Amigo, Á., Iroumé, A., Ulloa, H., and Castro, J.: Extraordinary sediment delivery and rapid geomorphic response following the 2008-2009 eruption of Chaitén Volcano, Chile, Water Resour. Res., 52, 5075-5094, https://doi.org/10.1002/2015wr018250, 2016.
Martha, T. R., Kerle, N., Jetten, V., van Westen, C. J., and Kumar, K. V.: Characterising spectral, spatial and morphometric properties of landslides for semi-automatic detection using object-oriented methods, Geomorphology, 116, 24-36, https://doi.org/10.1016/j.geomorph.2009.10.004, 2010.

Mergili, M. and Pudasaini, S. P.: r.avaflow - The mass flow simulation tool, available at: https://www.landslidemodels.org/r. avaflow/ (last access: 7 October 2021), 2014-2021.

Mergili, M., Fischer, J.-T., Krenn, J., and Pudasaini, S. P.: r.avaflow $\mathrm{v} 1$, an advanced open-source computational framework for the propagation and interaction of two-phase mass flows, Geosci. Model Dev., 10, 553-569, https://doi.org/10.5194/gmd-10-5532017, 2017.

Mergili, M., Frank, B., Fischer, J.-T., Huggel, C., and Pudasaini, S. P.: Computational experiments on the 1962 and 1970 landslide events at Huascarán (Peru) with r.avaflow: Lessons learned for predictive mass flow simulations, Geomorphology, 322, 15-28, https://doi.org/10.1016/j.geomorph.2018.08.032, 2018a.

Mergili, M., Emmer, A., Juřicová, A., Cochachin, A., Fischer, J.-T., Huggel, C., and Pudasaini, S. P.: How well can we simulate complex hydro-geomorphic process chains? The 2012 multi-lake outburst flood in the Santa Cruz Valley (Cordillera Blanca, Perú), Earth Surf. Proc. Land., 43, 13731389, https://doi.org/10.1002/esp.4318, 2018b.

Moreno, H., Varela, J., López-E,L., Munizaga, F., and Lahsen, A.: Geología y riesgo volcánico del volcán Osorno y centros eruptivos menores, Universidad de Chile, Departamento de Geología y Geofisica, Sangiago, 212 pp., 1985.

Moreno, H., Lara, L. E., and Orozco, G.: Geología del volcán Osorno, Región de Los Lagos, Servicio Nacional de Geología y Minería, Carta Geológica de Chile, Serie Geología Básica 126: p., 1 mapa escala 1:50.000, Santiago, 2010.

Moreno, T. and Gibbons, W. (Eds.): The Geology of Chile, The Geological Society of London, https://doi.org/10.1144/goch, 2007.

Naranjo, J. L., Sigurdsson, H., Carey, S. N., and Fritz, W.: Eruption of the Nevado del Ruiz Volcano, Colombia, On 13 November 1985: Tephra Fall and Lahars, Science, 233, 961-963, https://doi.org/10.1126/science.233.4767.961, 1986.

Oyarzún, J.: Análisis de los factores gatillantes al flujo hiperconcentrado en Villa Santa Lucía y determinación de las condicionantes de un proceso futuro, Trabajo de Proyecto de Titulación para optar al Título de Ingeniero Civil, Universidad de La Frontera, Facultad de Ingeniería y Ciencias, 2019.

Pierson, T. C.: Flow characteristics of large eruption-triggered debris flows at snow-clad volcanoes: constraints for debrisflow models, J. Volcanol. Geoth. Res., 66, 283-294, https://doi.org/10.1016/0377-0273(94)00070-w, 1995.

Pierson, T. C., Major, J. J., Amigo, Á., and Moreno, H.: Acute sedimentation response to rainfall following the explosive phase of the 2008-2009 eruption of Chaitén volcano, Chile, Bull. Volcanol., 75, 723, https://doi.org/10.1007/s00445-013-0723-4, 2013.

Pudasaini, S. P.: A general two-phase debris flow model, J. Geophys. Res., 117, F03010, https://doi.org/10.1029/2011jf002186, 2012.

Pudasaini, S. P. and Mergili, M.: A Multi-Phase Mass Flow Model, J. Geophys. Res.-Earth, 124, 2920-2942, https://doi.org/10.1029/2019jf005204, 2019. 
Qin, C.-Z., Bao, L.-L., Zhu, A.-X., Wang, R.-X., and Hu, X.-M.: Uncertainty due to DEM error in landslide susceptibility mapping, Int. J. Geogr. Inf. Sci., 27, 1364-1380, https://doi.org/10.1080/13658816.2013.770515, 2013.

Rodríguez, I., Páez, J., van Wyk de Vries, M. S., van Wyk de Vries, B., and Godoy, B.: Dynamics and physical parameters of the Lastarria debris avalanche, Central Andes, J. Volcanol. Geoth. Res., 402, 106990, https://doi.org/10.1016/j.jvolgeores.2020.106990, 2020.

Schaefer, L. N., Kennedy, B. M., Villeneuve, M. C., Cook, S. C. W., Jolly, A. D., Keys, H. J. R., and Leonard, G. S.: Stability assessment of the Crater Lake/Te Wai-ā-moe overflow channel at Mt. Ruapehu (New Zealand), and implications for volcanic lake break-out triggers, J. Volcanol. Geoth. Res., 358, 31-44, https://doi.org/10.1016/j.jvolgeores.2018.06.011, 2018

Schuster, R. L., NietoThomas, A. S., D. O'Rourke, T., Crespo, E., and Plaza-Nieto, G.: Mass wasting triggered by the 5 March 1987 ecuador earthquakes, Eng. Geol., 42, 1-23, https://doi.org/10.1016/0013-7952(95)00024-0, 1996.

Sepúlveda, S. A., Moreiras, S. M., Lara, M., and Alfaro, A.: Debris flows in the Andean ranges of central Chile and Argentina triggered by 2013 summer storms: characteristics and consequences, Landslides, 12, 115-133, https://doi.org/10.1007/s10346-0140539-0, 2014.

Sheridan, M. F., Stinton, A. J., Patra, A., Pitman, E. B., Bauer, A., and Nichita, C. C.: Evaluating Titan2D mass-flow model using the 1963 Little Tahoma Peak avalanches, Mount Rainier, Washington, J. Volcanol. Geoth. Res., 139, 89-102, https://doi.org/10.1016/j.jvolgeores.2004.06.011, 2005

Shu, H., Ma, J., Yu, H., Hürlimann, M., Zhang, P., Liu, F., and Qi, S.: Effect of Density and Total Weight on Flow Depth, Velocity, and Stresses in Loess Debris Flows, Water, 10, 1784, https://doi.org/10.3390/w10121784, 2018.

Sosio, R., Crosta, G. B., and Hungr, O.: Numerical modeling of debris avalanche propagation from collapse of volcanic edifices, Landslides, 9, 315-334, https://doi.org/10.1007/s10346011-0302-8, 2011.
Somos-Valenzuela, M. A., Oyarzún-Ulloa, J. E., Fustos-Toribio, I. J., Garrido-Urzua, N., and Chen, N.: The mudflow disaster at Villa Santa Lucía in Chilean Patagonia: understandings and insights derived from numerical simulation and postevent field surveys, Nat. Hazards Earth Syst. Sci., 20, 2319-2333, https://doi.org/10.5194/nhess-20-2319-2020, 2020.

Stern, C. R.: Holocene tephrochronology record of large explosive eruptions in the southernmost Patagonian Andes, B. Volcanol. 70, 435-454, https://doi.org/10.1007/s00445-007-0148-z, 2007.

Tacconi Stefanelli, C., Vilímek, V., Emmer, A., and Catani, F.: Morphological analysis and features of the landslide dams in the Cordillera Blanca, Peru, Landslides, 15, 507-521, https://doi.org/10.1007/s10346-017-0888-6, 2017.

Thouret, J.-C., Antoine, S., Magill, C., and Ollier, C.: Lahars and debris flows: Characteristics and impacts, Earth-Sci. Rev., 201, 103003, https://doi.org/10.1016/j.earscirev.2019.103003, 2020.

Vezzoli, L., Apuani, T., Corazzato, C., and Uttini, A.: Geological and geotechnical characterization of the debris avalanche and pyroclastic deposits of Cotopaxi Volcano (Ecuador). A contribute to instability-related hazard studies, J. Volcanol. Geoth. Res., 332, 51-70, https://doi.org/10.1016/j.jvolgeores.2017.01.004, 2017.

Wieczorek, G. F., Larsen, M. C., and Eaton, L. S.: Catastrophic landslides and flooding in coastal Venezuela, December 16, 1999 (abstr.). In Program with abstracts, 2000 Annual Meeting, Assoc. of Engrg. Geologists, San Jose, California, 19-26 September, AEG News, Vol. 43, p. 120, 2000.

Zwinger, T., Kluwick, A., and Sampl, P.: Numerical Simulation of Dry-Snow Avalanche Flow over Natural Terrain, in: Dynamic Response of Granular and Porous Materials under Large and Catastrophic Deformations, Springer Berlin Heidelberg, 161194, https://doi.org/10.1007/978-3-540-36565-5_5, 2003. 